\title{
Persistent initiation of DNA replication and chromatin-bound MCM proteins during the cell cycle in cdc6 mutants
}

\author{
Chun Liang and Bruce Stillman ${ }^{1}$ \\ Cold Spring Harbor Laboratory, Cold Spring Harbor, N ew York 11724 USA
}

\begin{abstract}
Faithful inheritance of genetic information requires that DNA be copied only once each cell cycle. Initiation of DNA replication involves the establishment of a prereplication complex (pre-RC) and subsequent activation by CDK/cyclins, converting the pre-RC to a post-RC. The origin recognition complex (ORC), Cdc6p, and the MCM proteins are required for establishing the pre-RC. We show that all six ORC subunits remain bound to chromatin throughout the cell cycle, whereas the MCM proteins cycle on and off, corresponding precisely to transitions of the RC. A newly isolated cdc6 mutant displays promiscuous initiation of DNA replication, increased nuclear DNA content, and constant MCM protein association with chromatin throughout the cell cycle. This gain-of-function cdc6 mutant ignores the negative controls imposed normally on initiation by the CDK/cyclins, suggesting that Codc6p is a key mediator of once-per-cell-cycle control of DNA replication.
\end{abstract}

[Key Words: DNA replication; ORC; Cdc6; MCM ; cell cycle; S. cerevisiae]

Received August 29, 1997; accepted in revised form October 8, 1997.

All eukaryotic cells duplicate the entire genome during the S phase of every cell cycle by initiating DNA synthesis from a large number of origins of DN A repl ication in each chromosome. Initiation is controlled by cis-acting replicators that are recognized by initiator proteins. To insure equal inheritance of all genetic material to each progeny cell, initiation at each origin must be tightly regulated so that it occurs just once during each S-phase.

Eukaryotic cell DNA replication has been studied most extensively in the budding yeast Saccharomyces cerevisiae, in which replicators have been defined genetically, origins of DNA replication have been physically mapped, and many initiation proteins and regulators have been identified (for review, see Diffley 1996; Stillman 1996). Homol ogs of some of the yeast initiation proteins have been identified recently in higher eukaryotes, and shown to be required for DN A replication (for review, see Chong et al. 1996; Jallepalli and Kelly 1997). In many species, however, the cis-acting elements (replicators) that may interact with these initiation proteins have not been defined.

The yeast initiator protein, origin recognition complex (ORC), binds directly to autonomously replicating sequences (ARS), the yeast replicators (Bell and Stillman 1992), and determines the location and frequency of firing of replication origins in chromosomes (Fox et al. 1995; Liang et al. 1995). Genomic footprints over ARS A

${ }^{1}$ Corresponding author.

E-MAIL stillman@cshl.org FAX (516) 367-8879. and B1 elements from isolated nuclei (Diffley and Cocker 1992; Diffley et al. 1994) resemble the nuclease digestion patterns of purified ORC bound to naked ARS DNA (Bell and Stillman 1992). This pattern of nuclease protection suggests, but does not demonstrate, that ORC remains bound to replicators throughout the cell cycle. The implied protein complex has been referred to as the post-replication complex (post-RC) and exists during $S$, $G_{2}$, and early $M$ phases of the cell cycle. At the $M \rightarrow G_{1}$ transition, however, a characteristic deoxyribonuclease I (DNase I) hypersensitive site in B1 is lost and an extended footprint appears (Diffley et al. 1994). This is believed to reflect the formation of a prereplication complex (pre-RC) containing additional proteins bound to the ARS or to ORC during late $M$ and $G_{1}$ phases.

Cdc6p is required for formation and maintenance of the pre-RC, as defined by the absence of the hypersensitive site at ARSs (Diffley et al. 1994; Cocker et al. 1996; Detweiler and Li 1997). The six sequencerel ated, minichromosome maintenance (MCM) proteins may also be part of the pre-RC, as they are required for DNA replication (Hennessy et al. 1991; Y an et al. 1993; Dalton and Whitbread 1995; C. Liang and B. Stillman, unpubl.). The MCM family members have been shown to bind to chromatin in yeast (Donovan et al. 1997), Xenopus egg extracts (Chong et al. 1995; Kubota et al. 1995; Madine et al. 1995; Coleman et al. 1996), and mammalian cells (Kimura et al . 1995; Todorov et al. 1995). Current models suggest that formation of a pre-RC at each origin determines that the replicator is competent for initiation of DN A replication at that locus. Once formed, the pre-RC needs to be activated by protein kinases C dc28p/C Ib5p// 
Clb6p) and Cdc7p/D bf4p, among other proteins, to trigger the onset of S-phase. Upon initiation, part of the pre$\mathrm{RC}$ is thought to be destroyed, reverting to a post-RC. Rebuilding of the pre-RC is prohi bited by the high kinase activities of $\mathrm{Cdc} 28 / \mathrm{Clb1}-6$ proteins in the $\mathrm{S}, \mathrm{G}_{2}$, and early $M$ phases of the cell cycle, therefore rereplication is prevented until the next cell cycle (for review, see $\mathrm{N}$ asmyth 1996; Stillman 1996; Jallepalli and Kelly 1997).

In this report, we show that ORC binds chromatin across the cell cycle, supporting the notion that ORC is a landing pad for other initiation proteins. In contrast, the chromatin binding of MCM proteins is tightly cell cycle regulated. MCM chromatin association and dissociation coincide with transitions in the state of the replication complex at origins. A newly isolated cdc6 mutant displ ays promiscuous initiation of DN A replication, increases in nuclear DNA content, and constant MCM protein association with chromatin throughout the cell cycle, despite the presence of high mitotic CDK activities, suggesting that the cdc6 mutant cells ignore the negative controls normally imposed on initiation of DNA replication by mitotic CDK cyclins.

\section{Results}

An assay for protein chromatin binding

A chromatin-binding assay (Fig. 1A) was developed to examine chromatin association of initiation proteins. Cells were spheroplasted and lyzed in a buffer containing Triton X-100. Chromatin, together with nuclear matrix and cell debris was spun down at low speed. The crude chromatin pellet at this stage is equival ent to that in the chromatin-binding assay with Xenopus egg extracts (Kubota et al. 1995; Coleman et al. 1996), and to a recently described assay in yeast (Donovan et al. 1997). To make sure that proteins in the crude pel let were actually bound to chromatin, we released $\sim 2$ - to 15-kb-long polynucleosomes from the pellet by limited micrococal nuclease ( $\mathrm{M} \mathrm{N}$ ase) digestion, and spun down the remaining material at low speed. Solubilized polynucleosomes were then pell leted by high speed ultracentrifugation. If a protein is found in the high speed pellet fraction, it should be chromatin bound.

Proteins in all seven fractions were resolved by gel electrophoresis and probed for ORC with a mixture of monoclonal antibodies (Fig. 1B; only Orc3p and Orc5p were assayed in this experiment). ORC was found in the whole cell extract (WCE; lane 1) and low-speed pellet (lane 3), but almost none in the low-speed supernatant (lane 2). Therefore, most of the cellular ORC was associated with chromatin or nuclear matrix, or both. A protein of $\sim 70 \mathrm{kD}$ that cross-reacted with the Orc3p antibody (labeled X) was partitioned to the low speed supernatant, thus serving as a nonchromatin-binding protein control. A bout half of the ORC in the low-speed pellet was released into solution by $\mathrm{MN}$ ase digestion (lane 4) and the rest remained in the pellet (lane 5). Limited, instead of complete, $\mathrm{MN}$ ase digestion was used so that the rel eased polynucleosomes were sufficiently large to be pell eted later by ul tracentrifugation (lane 7). ORC was detected in the high-speed pellet (lane 7), but not in the supernatant (lane 6). Therefore, ORC is a chromatinbound protein.

$\mathrm{Mcm} 2 \mathrm{p}$ also bound chromatin (Fig. 1C). It was detected by a monoclonal antibody in the WCE (lane 1), low-speed supernatant (lane 2), and low-speed pellet (lane 3). Therefore, not all of the cellular $\mathrm{M} \mathrm{cm} 2 \mathrm{p}$ bound chromatin at any given time. The $\mathrm{MN}$ ase-released $\mathrm{Mcm} 2 \mathrm{p}$ (lane 4) could be pel leted by ultracentrifugation (lane 7). Similar data (not shown) were obtained for Mcm3p.

To examine chromatin association of initiation pro-

Figure 1. A protein chromatin-binding assay. (A) Diagram of the chromatin-binding assay. Fractions are as follows. (1. WCE) whole cell extract from the total Iysate; (2. Sup) first low speed supernatant containing nonchromatinbinding proteins; (3. Pel) crude chromatin pellet; (4. Sup) polynucleosome-containing supernatant after limited $\mathrm{M} N$ ase digestion of the crude chromatin pellet; (5. Pel) remaining solid after $\mathrm{MN}$ ase digestion; (6. Sup) supernatant from ultracentrifugation; (7. Pel) high-speed pellet containing polynucleosomes. (B) All seven fractions from the chromatin-binding assay (except that the first low-speed pellet was not washed) using asynchronous W303-1A cells were Western blotted for Orc3 and Orc5 subunits. The same cell equival ent was loaded in all seven fractions. (X) cross-reacting band by the Orc3p antibody. (C) The same blot used in B was probed for $\mathrm{Mcm} 2 \mathrm{p}$. The arrow points to the upper band of endogenous $\mathrm{M} \mathrm{cm} 2 \mathrm{p}$, which comigrates with purified, baculovirus-expressed $M \mathrm{~cm} 2 \mathrm{p}$ from sf9 cells (data not shown, but see Fig. 2F). The lower
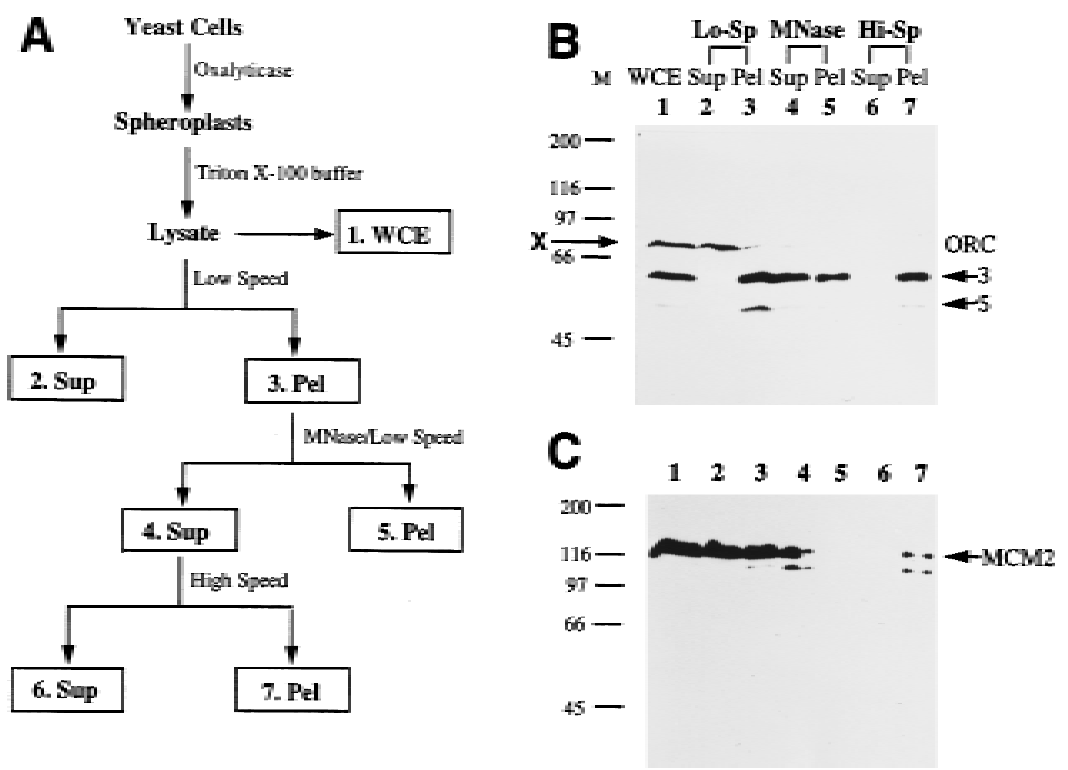
band is likely degradation product of $\mathrm{Mcm} 2 \mathrm{p}$. 
teins during the cell cycle, we assayed the crude chromatin fractions from the first low-speed centrifugation. Because all of the ORC and MCM released by MN ase from the crude chromatin pellets can be spun down by ultracentrifugation (Fig. 1B,C), it is reasonable to assume that most, if not all, of ORC and MCM proteins found in the crude chromatin pellets are chromatin bound.

\section{ORC binds chromatin throughout the cell cycle}

Cells were synchronized in $\mathrm{G}_{1}$ by $\alpha$ factor, then released into the cell cycle at $25^{\circ} \mathrm{C}$ and at various times, were processed for the chromatin-binding assay (Fig. 2). For ORC, only the chromatin fractions are shown (Fig. 2A), because very little ORC was in the supernatant (data not shown, but see Fig. 1B). Orc1, Orc3, Orc5, and Orc6 subunits were detected in the chromatin pellets from all of the time points (Fig. 2A). Orc2 and Orc4 subunits were al so found on chromatin across the cell cycle with darker exposures (data not shown). We conclude that ORC is associated with chromatin throughout the cell cycle.

The Orc6p band shifted up (almost merges with the
Orc5p band in this blot) as cells enter S-phase [30 min; see fluorescence-activated cell sorter (FACS) in Fig. 2B] and shifted down at $90 \mathrm{~min}$. The upper band of Orc6p is most likely attributable to phosphorylation, because Orc6p is phosphorylated in vivo and mutating all potential Cdc28p phosphorylation sites in ORC6 resulted in only the lower band (M. Weinreich, C. Liang, and B. Stillman, unpubl.).

Association of MCM with chromatin is cell cycle regulated and MCM is part of the pre-RC

A $\mathrm{Mcm} 3 p$ monoclonal antibody detected the protein at roughly constant levels across the cell cycle in the WCE (Fig. 2C) and supernatant (Fig. 2D). M ost of the cellular $\mathrm{Mcm} 3 p$ was not chromatin bound, as the levels in the supernatant were only slightly less than those in the WCE. Only small amounts were in the pellet (Fig. 2E). In contrast to ORC, the chromatin association of $\mathrm{Mcm} 3 \mathrm{p}$ was cell cycle dependent (Fig. 2E). $\mathrm{M} \mathrm{cm3p}$ bound chromatin in $\mathrm{G}_{1}$ ( $\alpha$ factor or $0-$, 10-, and 20-min time points),

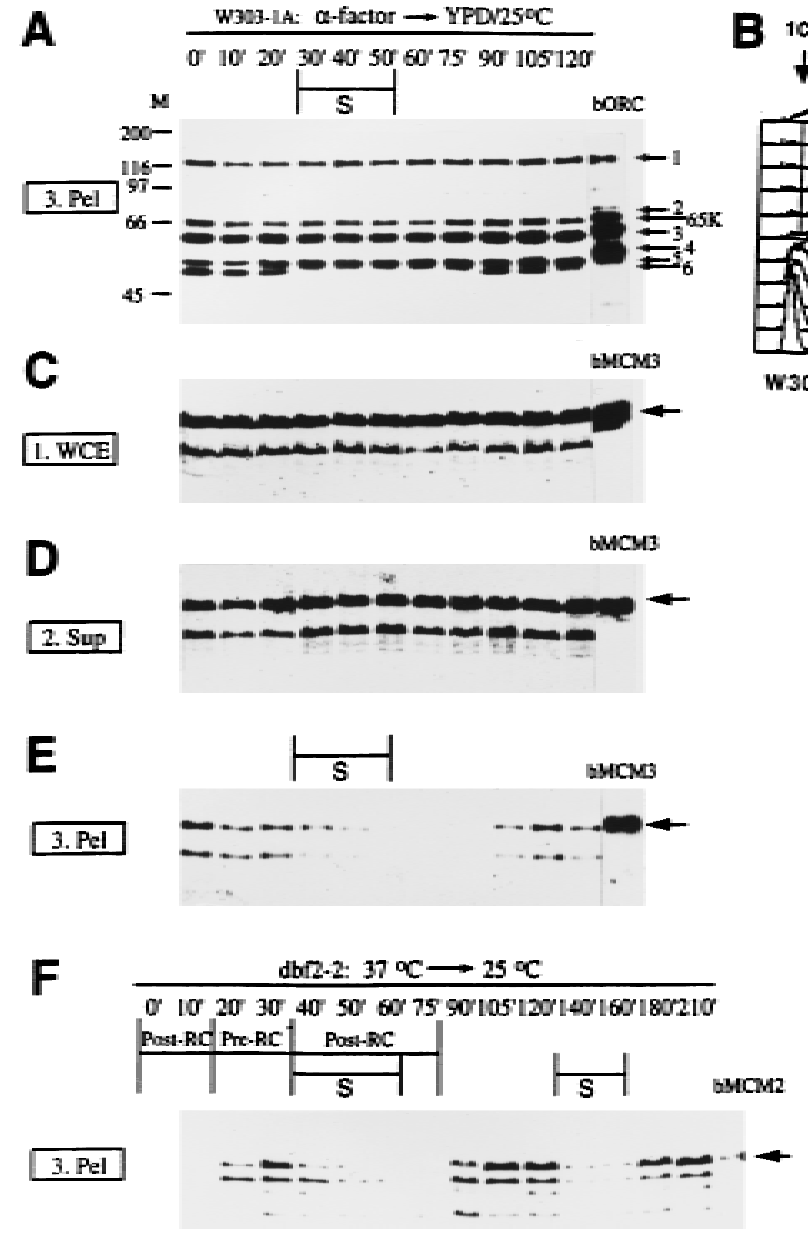

Figure 2. ORC binds chromatin throughout the cell cycle, whereas MCM chromatin association is cell cycle regulated. (A-E) W303-1A cells were synchronized in $G_{1}$ with $\alpha$ factor $(0$ min) and then released into fresh YPD medium at $25^{\circ} \mathrm{C}$. Samples were taken at various times (10-120 $\mathrm{min}$ ) after the release and processed to the first low-speed centrifugation of the chromatin-binding assay. $S$ phase was identified by FACS (B) as the period when DNA increases from $1 C$ to $2 C$. Western blots are shown for ORC in crude chromatin pellet (fraction 3. Pel; A) and for $M c m 3 p$ in fractions 1 . WCE (C), 2. Sup (D) and 3. Pel (E). A bout the same amount of proteins was loaded for each time point in each gel, and the same cell equival ent was loaded between WCE, Sup, and Pel (i.e., the signals from WCE should equal to those from Sup and Pel combined). bORC (A), bMCM 3 (C-E), and bMCM 2 (F) are purified baculovirus-expressed ORC, $M c m 3 p$, and $M c m 2 p$, respectively, from sf9 cells. Each ORC subunit, including the shifting of the Orc6p band, has been confirmed with individual antibodies (data not shown). Baculovirus-expressed Orc6p is phosphorylated, there fore, comigrates with Orc5p. (65K) degradation product of Orclp. Endogenous Orc2p and Orc4p bands are visible in all lanes in darker exposures (not shown). The arrows in C-E point to the upper band of the endogenous $\mathrm{Mcm} 3 p$ as well as $\mathrm{bM} \mathrm{cm} 3 p$. The lower band is a likely degradation product of $\mathrm{Mcm} 3 p$. (F) dbf2-2 homozygous (strain J2) cells were arrested in mitosis at $37^{\circ} \mathrm{C}$ ( $0 \mathrm{~min})$, and then released into the cell cycle by shifting to $25^{\circ} \mathrm{C}$. Samples were taken at various times (10 min-210 min) after the shift and fractionated into low-speed supernatant and pellet. Only the pellet fractions are shown. S-phases were identified by FACS (not shown). The postand pre-RC are marked according to Diffley et al. (1994). 
left chromatin as cells entered and progressed through S-phase (30-40 $\mathrm{min}$ ), and bound chromatin again at 90 min, the same time when Orc6p became dephosphorylated (Fig. 2A). Similar data (not shown) were obtained for $\mathrm{Mcm} 2 \mathrm{p}$.

The timing of MCM proteins starting to leave chromatin (Fig. 2E) as well as Orc6p phosphorylation (Fig. 2A) corresponded to the $\mathrm{G}_{1} \rightarrow \mathrm{S}$ transition, 30-40 min after cells were released from the $\alpha$ factor block. This is known to be the transition point from the proposed pre$R C$ to post-RC at the $G_{1} / S$ boundary (Diffley et al. 1994).

MCM proteins reappearing on chromatin and Orc6p dephosphorylation at $90 \mathrm{~min}$ after the release from the $\alpha$ factor correlated with reestablishment of the pre-RC at the end of mitosis. To test this possibility more vigorously, we performed chromatin-binding experiments with a homozygous dbf2-2 diploid strain that can be arrested in mitosis at the restrictive temperature of $37^{\circ} \mathrm{C}$ and then released synchronously into the next cell cycle at the permissive temperature of $25^{\circ} \mathrm{C}$. This same strain was used previously for genomic footprinting experiments to define the timing of the transition from post$\mathrm{RC}$ to pre-RC and then from pre-RC to post-RC (Diffley et al. 1994). At the restrictive temperature, dbf2-2 cells arrested in mitosis and had a post-RC footprint. The preRC was established $\sim 20$ min after the cells were shifted to the permissive temperature. The transition occurred at the end of mitosis (anaphase), right before mitotic spindles broke down. At $40 \mathrm{~min}$ after the release, as cells entered S-phase, the pre-RC then converted back to postRC (Diffley et al. 1994).

We used the same strain and conditions to examine $\mathrm{MCM}$ protein chromatin binding (Fig. $2 \mathrm{~F})$. At $37^{\circ} \mathrm{C}(0$ $\mathrm{min}$ ) or $10 \mathrm{~min}$ after the release, when the post-RC is known to be present, $M \mathrm{~cm} 2 \mathrm{p}$ was not associated with chromatin. $\mathrm{Mcm} 2 \mathrm{p}$ was on chromatin $20 \mathrm{~min}$ after release, the same time when the pre-RC was established. At the onset of S-phase, $40 \mathrm{~min}$ after the rel ease, $\mathrm{M} \mathrm{cm} 2 \mathrm{p}$ began to disappear from the chromatin as the pre-RC converted to the post-RC state. Similar data (not shown) were obtained for $\mathrm{Mcm} 3 \mathrm{p}$. These precise temporal correlations between $\mathrm{MCM}$ protein binding to chromatin and loss of the hypersensitive site in the genomic footprint (and vice versa) suggest that MCM proteins are part of the pre-RC. Reprobing for Orc6p on the same bl ot used for Figure 2F showed that Orc6p dephosphorylation and phosphorylation al so coincided with transition from the post-RC to pre-RC states and from the pre to post-RC states, respectively (data not shown). Therefore, it is likely that the post-RC contains ORC with phosphorylated Orc6p and the absence of MCM proteins, whereas MCM and ORC with dephosphorylated Orc6p are present in the pre-RC.

\section{New temperature-sensitive alleles of cdc6}

Several recent studies indi cate that Cdc6p is a key factor in DN A replication. Cdc6p is required for formation and maintenance of the pre-RC and loading of MCM onto chromatin, is required for initiation of replication, and cooperates with ORC on individual replicators to determine the frequency of initiation in the genome (Diffley et al. 1994; Liang et al. 1995; Cocker et al. 1996; Coleman et al. 1996; Piatti et al. 1996; Detweiler and Li 1997; Donovan et al. 1997). The levels of CDC6 mRN A and Cdc6 protein (at least the epitope tag version of Cdc6p) fluctuate in the cell cycle; both are high in late $M$ and early $G_{1}$, and very low in $S, G_{2}$, and early $M$ phases (Zhou and Jong 1990; Zwerschke et al . 1994; Piatti et al. 1995; Detweiler and Li 1997). CDC 6 has also been implicated in controlling mitosis entry (Bueno and Russell 1992). To investigate further the roles of Cdc6p in DNA replication, we carried out a PCR-based random mutagenesis of the gene followed by plasmid shuffling to uncover the properties of potential cdc6 mutants. Several new alleles of cdc6 temperature-sensitive mutants were thus isolated. Two of them (cdc6-2 and cdc6-3) show promiscuous replication phenotypes and were further characterized.

Cells contai ning a cdc6-2 plasmid as the sole source of cdc6p are very sick even at $25^{\circ} \mathrm{C}$ (Fig. 3A) and can accumulate $>2$ C DNA (data not shown), and we have not been able to integrate the mutant gene into the chromosome. cdc6-3 has been integrated into the chromosome, and the mutant has been characterized in more detail. cdc6-3 cells are viable at $25^{\circ} \mathrm{C}$ and lose viability at $37^{\circ} \mathrm{C}$ (Fig. 3A). The temperature-sensitive lethal phenotype of cdc6-3 was recessive; however, the mutant had a second phenotype of promiscuous replication even at the permissive temperature, which was dominant in the heterozygous diploid mutant cells.

When asynchronous cultures were shifted from $25^{\circ} \mathrm{C}$ to $37^{\circ} \mathrm{C}$, the wild-type cells (strain w303-1A) grew, whereas cdc6-3 cells did not (Fig. 3B), indicating a first cell-cycle arrest of the mutant cells. This was confirmed by incubating single cells on plates at $37^{\circ} \mathrm{C}$; the mutant cells did not divide as seen under a microscope. Moreover, the mutant cells lost viability at $37^{\circ} \mathrm{C}$ after an initial 1-hr delay (Fig. 3C).

After incubation at $37^{\circ} \mathrm{C}$, the wild-type cells divided normally, whereas cdc6-3 cells were arrested with large buds (dumb bell), undivided single nuclei either in one of the two buds or between the two buds, and short mitotic spindles (Fig. 3D; $37^{\circ} \mathrm{C}$ ). Therefore, the mutant cells failed to undergo mitosis at $37^{\circ} \mathrm{C}$.

Flow cytometry (FACS) was used to measure DNA content of the wild-type and cdc6-3 cells (Fig. 4). To avoid possible interference from mitochondrial DNA replication, we used corresponding $\rho^{\circ}$ strains lacking mitochondrial DN A for FACS analysis. When rel eased from the $\mathrm{G}_{1} \alpha$ factor block into fresh medium at $37^{\circ} \mathrm{C}$, wildtype cells progressed through the cell cycle and eventually became asynchronous (Fig. 4A; shaded). The mutant cells al so entered S-phase, al though with a del ay (cf. time points at 60 and $90 \mathrm{~min}$ to wild type), and in later time points most cells accumulated with $>2$ C DNA (Fig. 4A; unshaded; $160 \mathrm{~min}$ and $240 \mathrm{~min}$ ). Similar data were obtained with $\rho^{+}$strains of w303-1A and cdc6-3, although both the wild-type and mutant cells entered S-phase slightly faster than the respective $\rho^{\circ}$ strains (data not shown). 
A
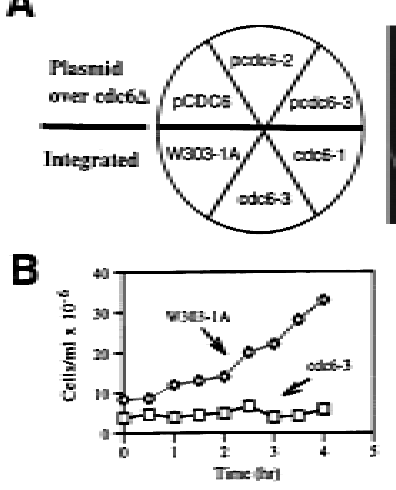

D
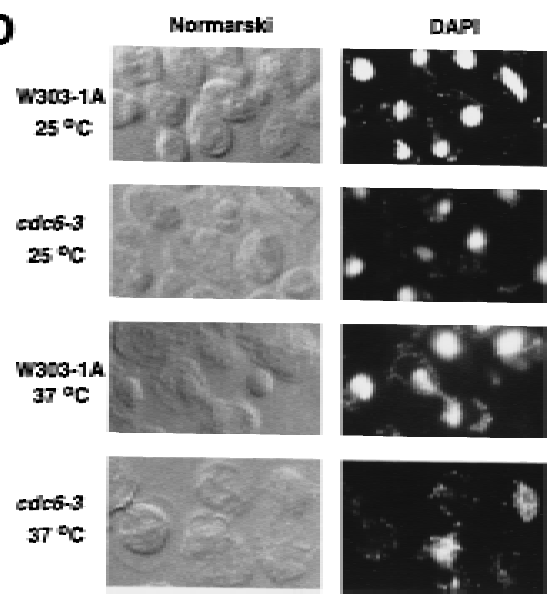

Figure 3. N ew al leles of cdc6 temperature-sensitive mutants. (A) top, cdc6 $\Delta$ strains harboring either pCDC6, pcdc6-2, or pcdc6-3 plasmid, and bottom, integrated strains (W303-1A as the isogenic wild-type cdc6-3, and for comparison, cdc6-1) were streaked on YPD plates and incubated for 3 days at 25 or $37^{\circ} \mathrm{C}$. (B) W303-1A and cdc6-3 cells were grown asynchronously at $25^{\circ} \mathrm{C}$ and then shifted to $37^{\circ} \mathrm{C}$. Aliquots of cells were harvested at various times and cell numbers counted. (C) Aliquots of cells were retrieved from $37^{\circ} \mathrm{C}$ at various times as in $\mathrm{B}$, single cells were plated and incubated at $25^{\circ} \mathrm{C}$. Percent viable is the fraction of cells able to form col onies at $25^{\circ} \mathrm{C}$, normal ized to the number of viable cells at time zero (i.e., $25^{\circ} \mathrm{C}$ ). (D) W303-1A and cdc6-3 cells were grown asynchronously at $25^{\circ} \mathrm{C}$ and then shifted to $37^{\circ} \mathrm{C}$ for $5 \mathrm{hr}$ (data from $3.5 \mathrm{hr}$ at $37^{\circ} \mathrm{C}$ were similar; not shown). Cells were fixed, prepared, stained with DAPI (for nuclei) and antitubulin antibody (for mitotic spindles), and visualized by N ormarski optics and fluorescence microscopy.

When the previously characterized cdc6-1 mutant cells were shifted to the restrictive temperature of $37^{\circ} \mathrm{C}$, they accumulated initially in $\mathrm{G}_{1}$ with $1 \mathrm{C}$ DNA, and then some cells went through reductional mitosis without replicating their DNA and ended up with $\angle 1 C$ DNA (Piatti et al. 1995; C. Liang and B. Stillman, unpubl.). This is similar to cel Is deprived of Cdc6p. Therefore, cdc6-1 is a loss-of-function mutation. On the other hand, cdc6-3 (al so pl asmid-borne cdc6-2; data not shown) mutant cells failed to undergo mitosis at $37^{\circ} \mathrm{C}$ (Fig. 3D) and had $>2 \mathrm{C}$ content of DNA (Fig. 4). Therefore, these are gain-offunction mutations. It is important to point out that other replication mutants such as orc2-1, orc5-1, cdc6-1, or mcm mutants did not accumulate $>2$ C DNA as measured by FACS (Gibson et al . 1990; Hennessy et al. 1991; Bell et al. 1993; Loo et al . 1995; C. Liang and B. Stillman, unpubl.), indicating that the phenotype was unique to cdc6-3.

Promiscuous replication of cdc6-3 mutant at the permissive temperature

The increase in nuclear DN A content above the normal post-S-phase 2C content in haploid cells could also be observed when cdc6-3 cells were released from the $\alpha$ factor block into the cell cycle at the permissive temperature of $25^{\circ} \mathrm{C}$. To prevent mitosis, nocodazole was added at $60 \mathrm{~min}$ postrelease. Wild-type cells entered the cell cycle and had a 2C DN A content by $90 \mathrm{~min}$ (Fig. 4B; shaded). cdc6-3 cel ls al so entered the cell cycle, and most cells had accumulated $\geqslant 2$ C DNA by $120 \mathrm{~min}$. By 240 min, however, most of the mutant cells had $\sim 3 C$ DN A (Fig. 4B; unshaded).

Cell size had little effect on the DNA profiles in the FACS analysis. Although cdc6-3 cells are larger than the wild type in asynchronous cultures at $25^{\circ} \mathrm{C}$ (by cell size measurement in FACS and microscopy observations; data not shown), the $G_{1}$ and $G_{2}$ DNA peaks were in the same position for the wild-type and mutant cells (Fig.
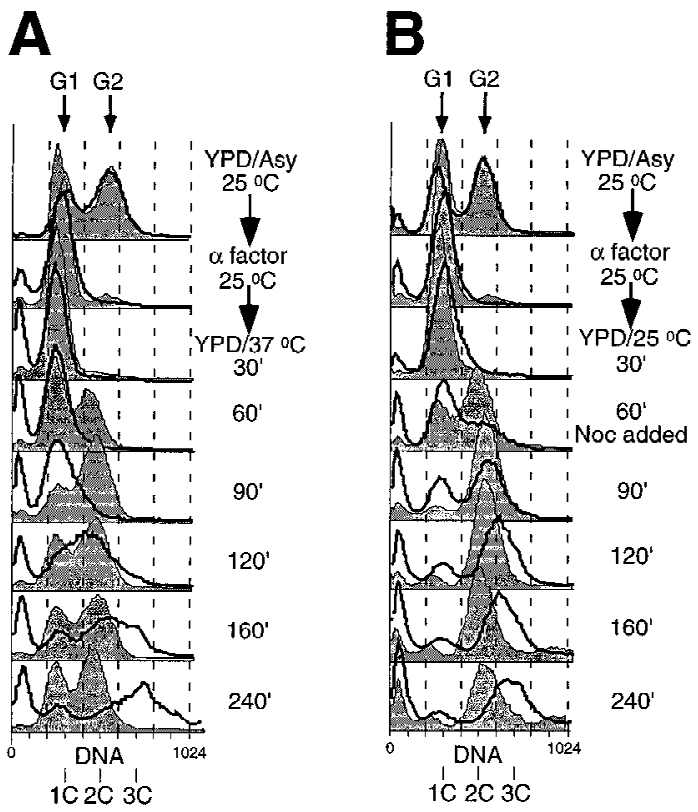

Figure 4. cdc6-3 mutant cells accumulate more than 2C DNA. $\rho^{\circ}$ strains of W303-1A (thin lines and shaded area) and cdc6-3 (thick lines and unshaded area) were grown asynchronously in $\mathrm{YPD}$ at $25^{\circ} \mathrm{C}\left(\mathrm{YPD} / \mathrm{Asy} / 25^{\circ} \mathrm{C}\right)$, blocked in $\mathrm{G}_{1}$ with $\alpha$ factor $(\alpha$ factor $/ 25^{\circ} \mathrm{C}$ ), and then released into fresh $Y P D$ at $37^{\circ} \mathrm{C}(\mathrm{A})$, or at $25^{\circ} \mathrm{C}$ and then nocodazole ( $\mathrm{N} \mathrm{oC}$ ) was added 60 min postrel ease (B). Aliquots of cells were taken at various times after the release and analyzed by FACS. DNA contents of $1 C$ and $2 C$, representing $G_{1}$ and $G_{2}$ cells, respectively, are marked. The peaks very close to the vertical axis (no DNA) are attributable to broken (from sonication) and dead cells, mainly of the mutant. 


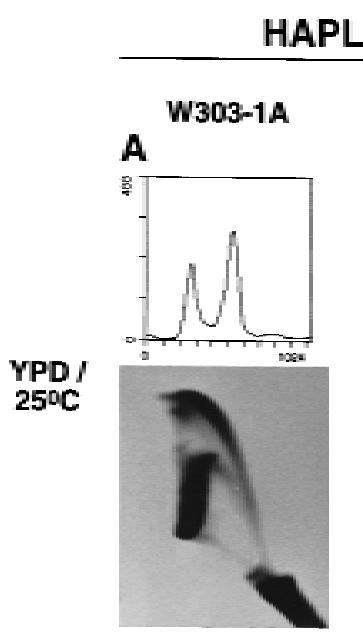

HAPLOID

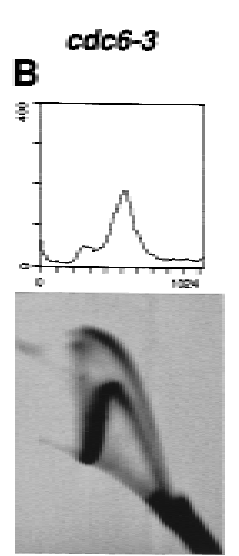

C

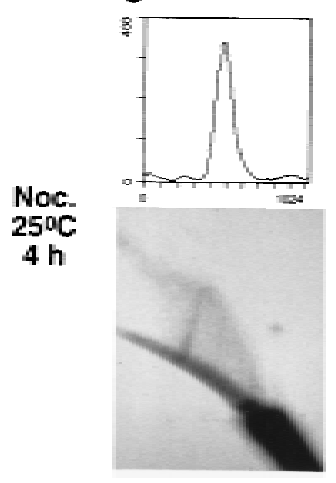

D

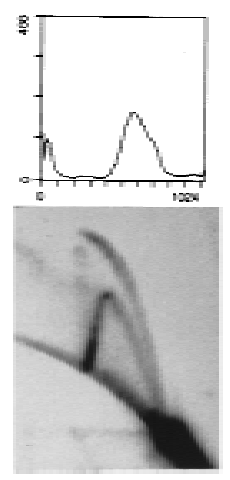

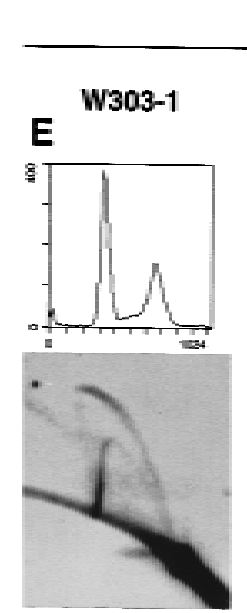

H

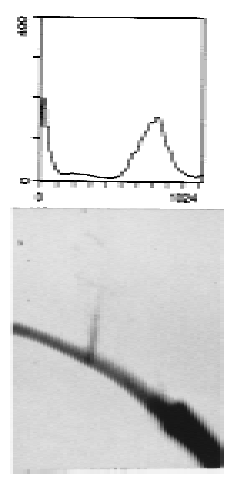

DIPLOID

$F^{\frac{\operatorname{codc6-3}}{\text { W303-1B }}} \quad \mathrm{G}^{\frac{\operatorname{cod} 6-3}{\operatorname{col} 6-3}}$

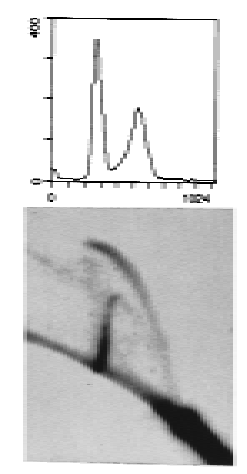

I

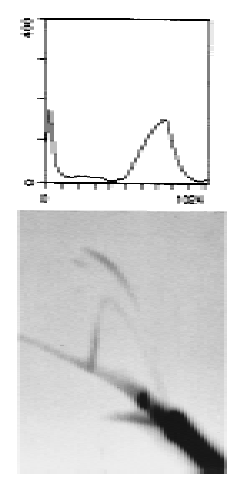

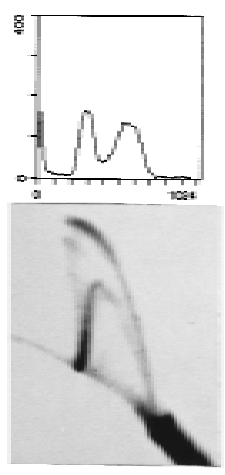

J

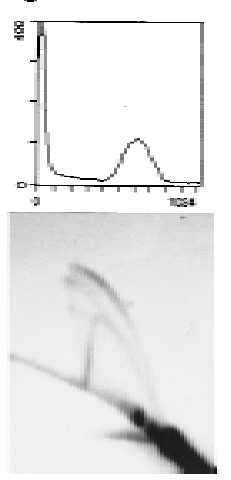

Figure 5. cdc6-3 cells initiate replication even in $G_{2} / M$ and this phenotype is dominant. Haploid (W303-1A and cdc6-3; $\left.A-D\right)$ and diploid strains (W303-1, cdc6-3/W303-1B and cdc6-3/cdc6-3; E-J) were grown asynchronously in YPD at 25 $5^{\circ}$ ( $A, B, E-G$ ), or incubated in YPD containing nocodazole at $25^{\circ} \mathrm{C}$ for $4 \mathrm{hr}(\mathrm{C}, \mathrm{D}, \mathrm{H}-\mathrm{J})$. Small al iquots of cells were analyzed by FACS and the remaining cells were processed for two-dimensional gels, which were probed for the 5-kb Ncol fraction containing ARS1 on the chromosome.

$4 \mathrm{~A}, \mathrm{~B} ; \mathrm{YPD} / \mathrm{Asy} / 25^{\circ} \mathrm{C}$ ). Furthermore, when cells were released from the $\alpha$-factor block into fresh medium and then blocked in $\mathrm{G}_{2} / \mathrm{M}$ by nocodazole, the wild-type cells reached the same size as the mutant cells (data not shown), yet only the mutant cells showed $>2 \mathrm{C}$ peaks (Fig. 4B). Therefore, the rightward shift in the DNA peaks beyond $2 \mathrm{C}$ in the haploid mutant cells was attributabl e to extranucl ear DN A rather than other biomass or fluorescence artifacts.

Two-dimensional replicon-mapping gels (2-D gels) were used to examine directly the initiation of DNA replication in the wild-type and cdc6-3 cells. Wild-type (W303-1A) or cdc6-3 mutant haploid cells either were grown asynchronously in the rich medium $Y P D$ at $25^{\circ} \mathrm{C}$ (Fig. 5A,B), or were incubated for $4 \mathrm{hr}$ at $25^{\circ} \mathrm{C}$ in YPD containing the microtubule inhibitor nocodazole, which blocked cells at $G_{2} / M$ (Fig. $5 C, D$ ). Cells were harvested, total DNA was prepared, digested with $\mathrm{Ncol}$, and enriched for replication intermediates. The enriched fractions from the same amount of total genomic DN A for each sample were resolved on 2-D gels. Bl ots of 2-D gels were probed for the $5-\mathrm{kb} \mathrm{Ncol}$ fragment containing ARS1, a normally fully active replication origin in wildtype cells (Liang et al. 1995 and references therein).
When grown in YPD, the vast majority of wild-type cel Is initiated replication from ARS1 in al most every cell cycle, as the two-dimensional gel shows an expected clear bubble-to-fork arc transition and very little fork migration through the origin (Fig. 5A). cdc6-3 cells gave a bubble arc in addition to a complete fork arc (Fig. 5B), indicating a lower frequency of initiation at ARS1 and subsequent passive replication through this locus, which was similar to results previously observed with cdc6-1, orc2-1, or orc5-1 mutants (Fox et al. 1995; Liang et al. 1995). In nocodazole-containing medi um, wild-type cells lacked a bubble arc as expected, as cells were arrested in $\mathrm{G}_{2} / \mathrm{M}$ (Fig. 5C; the fork arc probably represents a small number of cells not yet arrested at $G_{2} / M$ ). In striking contrast, cdc6-3 cells still had a clearly visible bubble arc, although they had been arrested in a $G_{2}$-like state with $\geqslant 2$ C DNA (Fig. 5D).

These data suggest that, unlike the wild-type, cdc6-3 cells initiated DNA replication in $G_{2} / M$, resulting in a DN A content more than the normal $2 \mathrm{C}$ amount. This promiscuous replication phenotype can explain why the mutant cells have difficulty entering into mitosis $(\sim 11 \%$ of asynchronous mutant cells have long mitotic spindles and $\sim 80 \%$ budded vs. $\sim 23 \%$ for the wild type with $\sim 40 \%$ 
budded) and lose viability in a fraction of the population (20-25\%), even at the permissive temperature.

To determine whether the promiscuous initiation phenotype was recessive or dominant, the initiation of DN A replication in homozygous wild type (W303-1), heterozygous (cdc6-3/W303-1B), and homozygous (cdc6-3/ cdc6-3) strains was investigated using the same procedures used for haploid cells. These analyses showed that this phenotype was dominant (Fig. 5E-J). Thus, the cdc6-3 mutant is a complex one, with a recessive, temperature-sensitive phenotype for growth, yet at the same time is a weak gain-of-function allele. When the gain-offunction phenotype was too penetrant, as in cdc6-2, this resulted in more over-replication and decreased strain viability (data not shown; see Fig. 3A). Because haploid cells also displayed the promiscuous replication phenotypes, we conclude that cdc6-3 is a dominant gain-offunction allele.

MCM protein chromatin association is cell cycle independent in cdc6-3 cells

Because MCM proteins appear to be components of the pre-RC, the binding of these proteins to chromatin was investigated in cdc6-3 cells during the cell cycle. Only the chromatin-bound fractions are shown (Fig. 6). As in wild-type cells, ORC was associated with chromatin throughout the cell cycle in cdc6-3 cells at $25^{\circ} \mathrm{C}$ (Fig. $6 \mathrm{~A})$. The timing of Orc6p phosphorylation and dephosphorylation during the cell cycle was similar to the wild type (cf. Figs. 2A and 6A), indicating that cdc6-3 cells progressed through some aspects of the cell cycle with similar kinetics as wild-type (also see FACS; Figs. 2B and $6 B)$. Unlike in wild-type cells, however, $M c m 3 p$ was bound to chromatin throughout the entire cell cycle in cdc6-3 cells (Fig. 6C). Similar data (not shown) were obtained for $M \mathrm{~cm} 2 \mathrm{p}$. This was not attributable to the low frequency of initiation in cdc6-3, because most, if not all, of cdc6-3 cells entered S phase and accumulated a fully replicated $\geqslant 2 C$ amount of DNA after release from the $\alpha$ factor block (Fig. 6B). Moreover, cdc6-1 and orc5-1 cells also have a lower than normal frequency of initiation at the permi ssive temperature (Liang et al . 1995) similar to that of cdc6-3, yet the chromatin association of MCM proteins in cdc6-1 and orc5-1 mutants was cell cycle regulated in a similar manner as found in wild-type cells; that is, Mcm2p (Fig. 7A) and Mcm3p (data not shown) were not chromatin bound in $\mathrm{S}$ and $\mathrm{G}_{2}$. Also notice that unlike cdc6-3, orc5-1 or cdc6-1 cells did not accumulate >2C DNA when they were released from the $\alpha$ factor block (Fig. 7B). These data demonstrate that the continuous binding of MCM proteins in cdc6-3 cells was not attributable to slow progression through $S$ phase, but rather is specific for this particular form of mutant cdc6 protein.

$\mathrm{M} \mathrm{cm} 2$ and $\mathrm{M} \mathrm{cm} 3$ proteins were al so found in the highspeed pellet (polynucleosomes) from cdc6-3 cells arrested at $\mathrm{G}_{2} / \mathrm{M}$ by nocodazole (data not shown), confirming that the MCM proteins found in the low-speed crude chromatin pellets from $\mathrm{S}$ and $\mathrm{G}_{2}$ cdc6-3 cells (Fig. 6C) were actually chromatin bound.

T ogether, these data indicate that the competent state of replicators in $S$ and $\mathrm{G}_{2}$ in cdc6-3 cells includes chromatin-bound MCM proteins, probably together with the mutant cdc6-3 protein. We have not been able to detect clearly endogenous Cdc6p or cdc6-3p in crude yeast extracts or chromatin fractions with the available Cdc6p antibodies.

Promiscuous initiation occurs despite high $\mathrm{Cdc} 28 / \mathrm{Clb}$ kinase activities

The avail able evidence suggests that $\mathrm{Cdc} 28 / \mathrm{Cl}$ b5//Clb6) kinases normally activate replication at the $G_{1} / S$ boundary and then the mitotic CDK cyclins inhibit rereplication in $\mathrm{S}$ and $\mathrm{G}_{2}$ (Schwob et al. 1994; Dahmann et al. 1995; Piatti et al. 1996). Moreover, Cdc28p interacts with Cdc6p (El sasser et al . 1996; Piatti et al. 1996). Similar interactions occur with the equivalent proteins in Schizosaccaromyces pombe (Jallepalli and Kelly 1997).

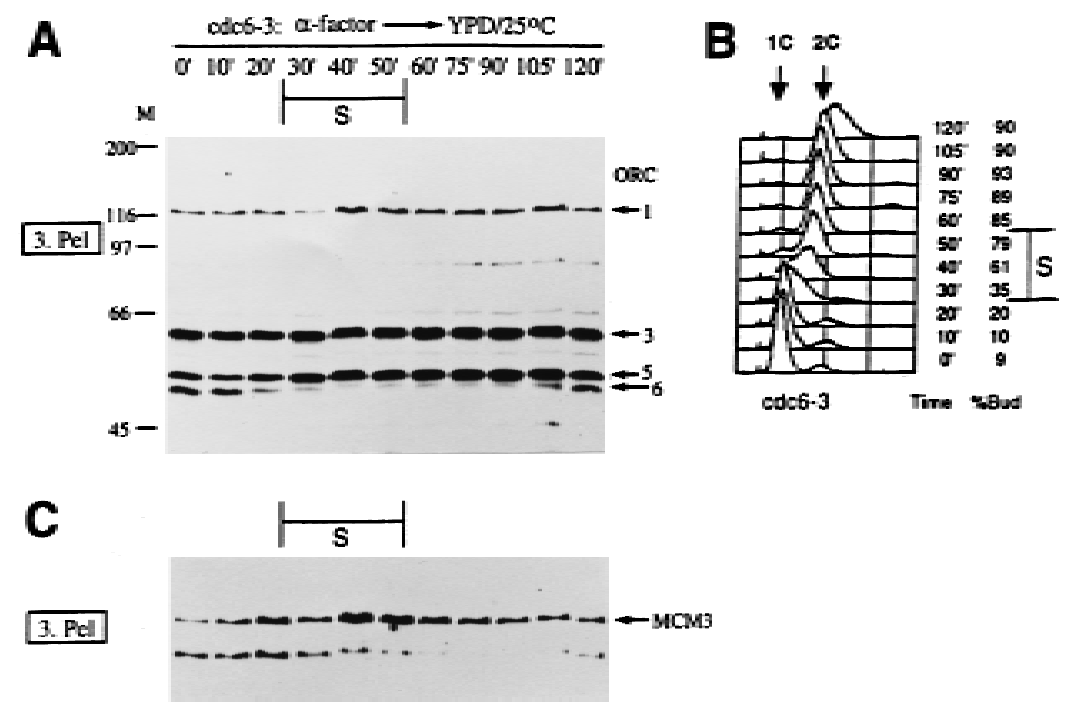

Figure 6. MCM protein chromatin association is cell cycle independent in cdc6-3 cells. Chromatin-binding experiments were carried out with cdc6-3 cells in the same way as W303-1A cells in Fig. 2. Only the crude chromatin pellet fractions were shown for ORC (A) and $M \mathrm{~cm} 3 p$ (C). The endogenous ORC (Orc2 and Orc4 bands visible only in darker exposures; not shown) and $\mathrm{Mcm} 3 p$ were detected in all lanes. Small al iquots of cells were analyzed by FACS (B). 


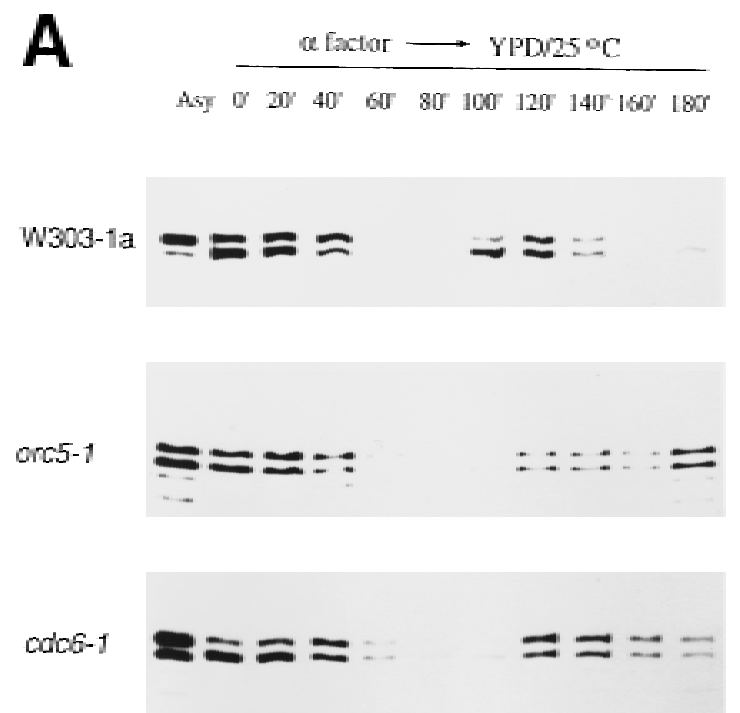

Chromatin-bound Mcm2

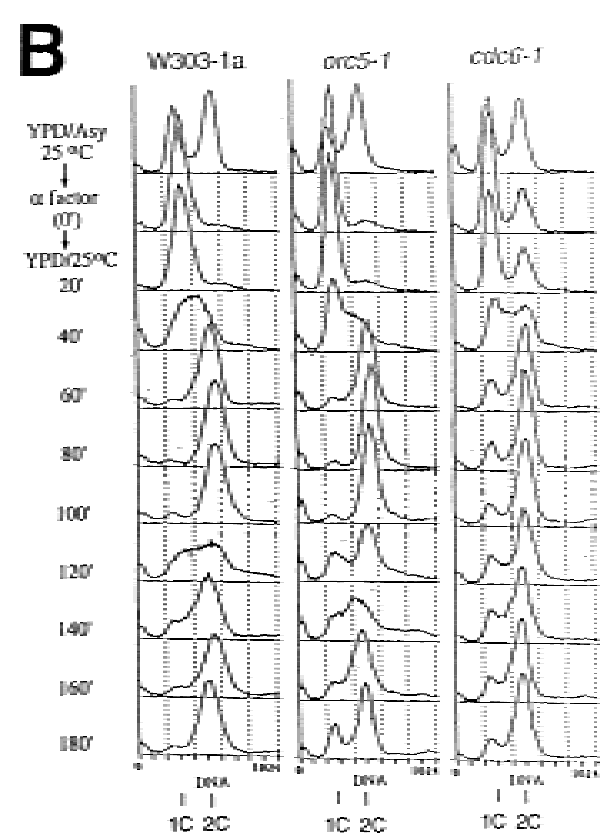

Figure 7. MCM protein chromatin binding is cell cycle regulated in orc5-1 and cdc6-1 mutants. Chromatin-binding experiments were carried out with W303-1a, orc5-1 or cdc6-1 cells across the cell cycle, and the chromatin bound M cm2p was assayed (A). Small al iquots of cells were analyzed by FACS (B). (Asy) asynchronous cells; (0 min) $\alpha$ factor blocked cells.

Therefore, it was conceivable that in wild-type cells, once the pre-RC converted to a post-RC state after initiation, the high CDK activities in $\mathrm{S}$ and $\mathrm{G}_{2}$ prevented reassociation of MCM proteins with chromatin by blocking Cdc6p function. Because we found that the MCM proteins remained chromatin bound during the cell cycl e in cdc6-3 cells, we asked whether there was an absence of high CDK activities in cdc6-3 cells, or promiscuous initiation occurs despite the high CDK activities.

Either wild-type or cdc6-3 cells were released into the cell cycle at $25^{\circ} \mathrm{C}$ from the $\mathrm{G}_{1} \alpha$ factor block, and samples were taken at various times after the release. $\mathrm{N}$ ative proteins were extracted, $\mathrm{Cdc} 28 \mathrm{p}$ was precipitated with p13/Sucl-agarose beads, and assayed for histone H1 kinase activity (Fig. 8).

Control glutathion-agarose beads did not pull down the kinase (Fig. 8; Ctrl bead). The histone $\mathrm{H} 1$ kinase activity across the cell cycle in the wild-type cells was found to be as expected (Schwob et al. 1994 and references therein). It was low in $\alpha$ factor-blocked cells, increased at $20 \mathrm{~min}$ after the release, and rose to higher levels after $40 \mathrm{~min}$. The last lane shows the expected high kinase activity when cells were arrested at $G_{2} / M$ with nocodazole for $4 \mathrm{hr}$ at $25^{\circ} \mathrm{C}$. The kinase activity during the cell cycle for the cdc6-3 cells was very similar to those for wild-type cells. N otice that the kinase activity from cdc6-3 cells that were in nocodazole-containing medium was as high as wild type, yet cdc6-3, but not wild-type cells, were able to initiate DNA replication under these conditions (see Fig. 5C,D). Therefore, M CM protein chromatin association and initiation of DNA replication in cells arrested at $G_{2} / M$ in cdc6-3 cells in the presence of the normal level of Cdc28 kinase activities. These results suggest that the negative control by mitotic cyclins on establishing the pre-RC is mediated through Cdc6p. cdc6-3 mutant cells ignore this negative control and promiscuous initiation of DNA replication occurs.

\section{Discussion}

ORC is a sequence-specific DNA-binding protein that binds to replicators that determine the location of origins of DNA replication in S. cerevisiae (Bell and Stillman 1992). Genomic footprinting experiments have sug-

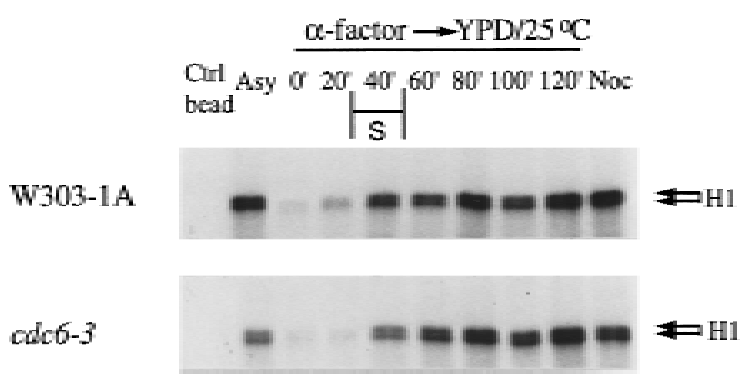

Figure 8. The $C D K$ activities in $S$ and $\mathrm{G}_{2}$ in cdc6-3 are as high as in the wild-type cells. W303-1A and cdc6-3 cells were grown asynchronously in $\mathrm{YPD}$ at $25^{\circ} \mathrm{C}$ (Asy), synchronized in $\mathrm{G}_{1}$ with $\alpha$ factor $(0 \mathrm{~min})$ and then released into fresh $Y P D$ at $25^{\circ} \mathrm{C}$. Samples were taken at various times (20-120 min) after the release. The last lanes (Noc) were from cells incubated in YPD containing nocodazole at $25^{\circ} \mathrm{C}$ for $4 \mathrm{hr}$. Native proteins were extracted and used for $\mathrm{p} 13$ bead precipitation. The precipitates were assayed for histone $\mathrm{H} 1$ kinase activities. 
gested that ORC binds the replicator throughout most, if not all, of the cell cycle (Diffley and Cocker 1992; Diffley et al . 1994). Our chromatin-binding assay provides direct physical evidence that all ORC subunits remain bound to chromatin at all times, and thus ORC has the potential to serve as the DNA-bound landing pad for other initiation proteins. It is most likely that ORC is bound to repl icator sequences in chromatin, a result demonstrated recently by Tanaka et al. (1997). On the other hand, MCM proteins bind chromatin in a cell cycle-dependent fashion, consistent with them being part of the mechanism that licenses repl ication in yeast, as has been demonstrated in Xenopus egg extracts (for review, see Chong et al. 1996). A recent chromatin-binding study using cell cycle inhibitors and cdc mutants shows that MCM is on chromatin in $\mathrm{G}_{1}$ ( $\alpha$ factor and cdc7), much less so in $\mathrm{S}$ (hydroxyurea), and not at all in $\mathrm{G}_{2} / \mathrm{M}$ (nocodazole and cdc15) (Donovan et al. 1997).

The idea of two states (pre- and post-RC) of proteins bound to the replicator has come from genomic footprinting studies, principally from the absence and presence, respectively, of a DNase I hypersensitive site within the ARS B1 element (Diffley et al. 1994). We have shown that MCM proteins bind chromatin when the hypersensitive site is absent (pre-RC) in late $M$ and $G_{1}$, and are not on chromatin when the hypersensitive site is present (post-RC) in $S, G_{2}$, and early $M$ phases. Coupled with the observation that immunoprecipitation of tagged $\mathrm{M} \mathrm{cm} 7 \mathrm{p}$ coprecipi tated repl ication origin containing DN A (Tanaka et al . 1997), these data suggest strongly that chromatin-bound MCM proteins are part of the pre$\mathrm{RC}$ and contribute to protection at the Bl site from DN ase I.

The number of ORC molecules ( 600) in the cell roughly equal s the number of replication origins, but the MCM proteins are at least 20 times more abundant (Lei et al. 1996; Donovan et al. 1997). The amount of chromatin-bound Cdc6p in $G_{1}$ also approximates that of the number of replication origins (Donovan et al. 1997). Paradoxically, $\mathrm{Mcm} 2 \mathrm{p}$ appears to be limiting for replication (Lei et al. 1996). Only a small fraction, however, of the cellular MCM proteins bind chromatin. Therefore, it is likely that the fraction of chromatin-bound M CM proteins that is detected by our procedure and by others (Donovan et al . 1997; Tanaka et al . 1997), as well as ORC and Cdc6 proteins, acts at individual replicators, rather than globally on the chromosomes. Consistent with this notion, mutants in five of the MCM family of genes have reduced frequencies of initiation (Yan et al. 1993; C. Liang and B. Stillman, unpubl.).

Our analysis of the cdc6-3 gain-of-function mutants reveal ed three interesting and related phenotypes. First, the mutant cells accumulate abnormal amounts of nuclear DNA without passing through mitosis. Second, two-dimensional gel analyses suggest that initiation of DN A replication occurs late in the cell cycle when it is normally inhibited in wild-type cells. Third, the MCM proteins remain bound to the chromatin at times when they are not bound in other cells. Combined, these phenotypes suggest that the cell cyclecontrol of initiation of
DN A replication is awry in the cdc6-3 mutant cells, resulting in over-replication of the genome, leading to genetic instability and inviability.

Cdc6p interacts with ORC, and is required for loading of MCM proteins onto chromatin, formation of the preRC, and initiation of DN A replication (Liang et al . 1995; Cocker et al. 1996; Coleman et al. 1996; Piatti et al. 1996; Detweiler and Li 1997; Donovan et al. 1997). Cdc6p can execute its function between the end of anaphase and late $G_{1}$, before activation of replication by Cdc28p/CIb5p and C Ib6p kinases (Piatti et al . 1996). Formation of the pre-RC in the rest of the cell cycle is prevented by high CDK activities of Cdc28p/CIb cyclins (Dahmann et al. 1995), and high levels of Cdk2/cyclin E inhibit $\mathrm{Mcm} 3 \mathrm{p}$ chromatin binding and replication in Xenopus egg extracts (Hua et al. 1997). Because a cdc6 mutant can bypass the CDK inhibition of rereplication, we propose that this negative regulation is mediated through Cdc6p.

cdc6-3 mutant cells have a lower frequency of initiation of DNA replication at any given origin, similar to cdc6-1 and several orc (Fox et al. 1995; Liang et al. 1995) and mcm mutants (Yan et al . 1993; C. Liang and B. Stillman, unpubl.), probably attributable to lower concentrations (Bell et al. 1993; Loo et al. 1995) or lower activity of these initiation proteins. When shifted to the restrictive temperature, the frequency of initiation is further reduced so that these mutant cells are arrested in the cell cycle and die. However, unlike cdc6-1 or orc mutants, cdc6-3 cells continue to initiate DNA replication even after $3 \mathrm{hr}$ at the restrictive temperature in the presence of nocodazole, al beit at a lower frequency than wild type, leading to accumulation of $\geqslant 3 C$ DNA and eventually cell inviability. The loss of cell viability, as detected by the inability to form colonies on plates at the permissive temperature, is probably attributabl e to the increased genetic instability in the cdc6-3 mutants as a result of the promiscuous initiation of replication.

The promiscuous initiation of DNA replication in the cdc6-3 mutant was al so observed even at the permissive temperature in a single cell cycle. This phenotype was dominant, but probably not fully penetrant because such a mutant would cause too much genome instability and cell death. The cdc6-2 mutant over-replicated its DN A more than cdc6-3 (data not shown), and these cells were less viable than cdc6-3 cells.

Persistent initiation of DNA replication and MCM protein chromatin association in cdc6-3 cells occur although the $\mathrm{Cdc} 28 / \mathrm{Clb}$ kinase activities in $\mathrm{S}$ and $\mathrm{G}_{2}$ in the mutant cells were as high as in wild-type cells. It is possible that the function of Cdc6p to load MCM proteins is regulated by the CDK cyclins, perhaps through the ATP-binding site in Cdc6p, and that the mutant cdc6 protein is locked into a constitutively active conformation, rendering it immune to the inhibitory effects of the mitotic cyclins. As a result, either the MCM proteins remain bound on replicated chromatin and initiation of DNA replication can occur even in $G_{2} / M$, or that initiation complexes containing MCM proteins can be re formed continually, even in the presence of high mitotic 
CDK activity. This was specific for cdc6-3 cells, and was not observed in other mutants that have a lower frequency of initiation than wild-type cells. Thus, the promiscuous initiation of replication and constant chromatin binding of MCM protein in cdc6-3 cells were not attributable to slow S-phase progression.

Rereplication phenotypes in S. cerevisiae have been reported in the ubiquitin hydrolase (Singer et al. 1996) and cdc16 and cdc27 mutants (Heichman and Roberts 1996). Currently, the relationship between these and CDC 6 genes is unknown. Overexpression of the Cdc6related protein called cdc18 ${ }^{+}$in S. pombe, ei ther directly or indirectly, causes multipl e rounds of replication of the genome without mitosis (Nishitani and Nurse 1995; Muzi-Falconi et al. 1996). In all of these cases, over-replication could be attributable to the high levels of proteins that are normally degraded by ubiquitin-mediated proteolysis indirectly affecting CDK/cyclin activity late in the cell cycle. This could result in a block to mitosis but allow multiple rounds of $S$ phases in these cells.

The phenotype of the cdc6-3 mutant is remarkably similar to the promiscuous initiation of DN A replication found in the Escherichia coli DnaAcos mutant (Katayama 1994; Katayama and Kornberg 1994). The DnaA initiator protein binds to O riC origin in its active ATPbound form, slowly hydrolyzes the ATP to form an inactive ADP-bound form that cannot initiate replication (for review, see Skarstad and Boye 1994). DnaAcos is a revertant of the DnaA46 temperature-sensitive mutant and like cdc6-3, contains multiple mutations. The DnaAcos protein causes promiscuous initiation of DNA replication in vivo and in vitro by overcoming an unknown negative regulation of initiation. Interestingly, the mutant protein cannot bind ATP. We suggest that the normal function of Cdc6p may also be sensitive to ATP, just like the DnaA initiator and its eukaryotic sequence relative in the ORC complex Orclp (Bell et al. 1995; Klemm et al. 1997). Therefore, it is possible that cdc6-3p may have unregulated ATP binding, causing an altered conformation and resistance to negative control by the CDK cyclins. Finally, we consider it probable that Cdc6p may control the switch to amplification cycles during development in certain cell types, such as the ORC-dependent amplification of the chorion genes in Drosophila (Landis et al. 1997).

\section{Materials and methods}

Yeast strains and plasmids

All yeast strains used were, or derivatives of, W303-1A (M ata), W303-1B (M at $\alpha$ ) (ho, ade2, trp1, can1, leu2, his3, GAL, psi ${ }^{+}$), or W303-1 (W303-1A/W303-1B), except for strain J2 (dbf2-2/ dbf22) (Diffley et al. 1994) used in Figure 2F. All cdc6 $\Delta$ strains were derived from strain GS1 (W303-1; cdc6s::hisG-URA3-hisG/ CDC6), kindly provided by Gavin Sherlock and Bruce Futcher of Cold Spring Harbor Laboratory, in which all but the first and last $50 \mathrm{bp}$ of one copy of the CDC6-coding sequence has been del eted on the basis of the PCR-directed gene disruption method (Schneider et al. 1996). The U RA3 gene used to disrupt CDC6 was later inactivated by use of 5 -fluoro-orotic acid. The following strains are cdc6s in W303-1A containing pRS426-
CDC6 (YB0209), pRS415-2.1CDC6 (YB0321), pRS415-cdc6-2 (YB0275), or pRS415-cdc6-3 (YB0276). YB0297 is cdc6-3 integrated in W303-1A by transplacement, and YB0044 is Mata, cdc6-1 (backcrossed four times to W303; Liang et al. 1995). $\rho^{\circ}$ strains (YB0433 from W303-1A and YB0434 from cdc6-3) were generated by growing the $\rho^{+}$strains in SCM medium containing $20 \mu \mathrm{g} / \mathrm{ml}$ of EtBr overnight at $25^{\circ} \mathrm{C}$ and then selecting for inability to grow on glycerol plates. Diploid strains were YB0325 (cdc6-3/W303-1B) and YB0323 (cdc6-3/cdc6-3).

pRS426-CDC6 is the 3.1-kb Mlul-EcoRI CDC6 fragment cloned in pRS426 ( $2 \mu$ ARS, URA3) by exchanging the vectors with pRS415-CDC6 (Liang et al. 1995). pKS-2.1CDC6 was constructed by ligating the 2.1-kb HindlIINarl CDC6 fragment from pRS415-CDC6 (Hindlll site is in the vector just upstream of the Mlul site of the CDC6 promotor) to pBluescript/KS+ (Strategene) cut with HindIII and Clal. pRS415-2.1CDC6 (shorthanded as $\mathrm{pCDC6}$ ) was constructed by ligating the 2.1-kb HindIII-Xhol (both sites on vector) fragment containing CDC 6 from pKS-2.1CDC6 to pRS415 (CEN6, H4 ARS, LEU 2) cut with the same enzymes. pRS415-cdc6-2 (as pcdc6-2) and pRS415-cdc6-3 (as pcdc6-3) were derived from pRS415-2.1CDC6 by random mutagenesis.

\section{Cell synchronization and release}

Cells were grown in YPD at $25^{\circ} \mathrm{C}$ to early log phase $\left(\sim 5 \times 10^{6}\right.$ cells $/ \mathrm{ml}$ ), $\alpha$ factor was then added to $5 \mu \mathrm{g} / \mathrm{ml}$, and the culture was incubated with shaking for $1.5 \mathrm{hr}$ at $25^{\circ} \mathrm{C}$. A nother $5 \mu \mathrm{g} / \mathrm{ml}$ of $\alpha$ factor was added, and the culture was incubated for another $1.5 \mathrm{hr}$ at $25^{\circ} \mathrm{C}$. To release, cells were spun down, and resuspended in fresh YPD. Rapid shifting to $37^{\circ} \mathrm{C}$ was achieved by swirling culture flasks in $\sim 50^{\circ} \mathrm{C}$ water. N ocodazole $(20 \mu \mathrm{g} / \mathrm{ml})$ was used to arrest cells in $\mathrm{G}_{2} / \mathrm{M}$. YPD with $4 \%$ dextrose was used for the $\rho^{\circ}$ strains.

\section{Protein chromatin-binding assay}

A bout $1 \times 10^{9}$ cells at $\sim 2 \times 10^{7}$ cells $/ \mathrm{ml}$ were harvested and sodium azi de was added to $0.1 \%$. Cells were spheropl asted according to Conradt et al. (1992) with modifications. Cells were incubated at room temperature for $10 \mathrm{~min}$ in $3 \mathrm{ml}$ of prespheroplasting buffer [100 mM PIPES (pH 9.4), $10 \mathrm{~mm}$ DTT], followed by incubation in $2 \mathrm{ml}$ of spheroplasting buffer [50 $\mathrm{mM} \mathrm{KH}_{2} \mathrm{PO}_{4} /$ $\mathrm{K}_{2} \mathrm{HPO}_{4}(\mathrm{pH} 7.5), 0.6 \mathrm{M}$ Sorbitol, $10 \mathrm{~mm}$ DTT] containing $80 \mu \mathrm{l}$ of $1 \mathrm{mg} / \mathrm{ml}$ of Oxalyticase (Enzogenetics) at $30^{\circ} \mathrm{C}$ for $10-15 \mathrm{~min}$ with occasional mixing, until the $\mathrm{OD}_{600}$ of a $1: 100$ dilution of the cell suspension (in water) dropped to $<10 \%$ of the value before digestion. Sphereoplasts, without incubation for recovery and regrowth, were washed with $1 \mathrm{ml}$ of ice-chilled wash buffer [100 mM KCl, $50 \mathrm{~mm}$ HEPES-KOH (pH 7.5), $2.5 \mathrm{~mm} \mathrm{M} \mathrm{gCl}$, and $0.4 \mathrm{M}$ Sorbitol], pelleted at $4000 \mathrm{rpm}$ for $1 \mathrm{~min}$ in a microcentrifuge at $4^{\circ} \mathrm{C}$, and resuspended in an equal pellet volume $(\sim 80$ $\mu \mathrm{l}$ ) of extraction buffer [EB; $100 \mathrm{~mm} \mathrm{KCl}, 50 \mathrm{~mm}$ HEPES-KOH (pH 7.5), $2.5 \mathrm{~mm} \mathrm{M} \mathrm{gCl}_{2}, 50 \mathrm{~mm} \mathrm{NaF}, 5 \mathrm{~mm} \mathrm{Na}_{4} \mathrm{P}_{2} \mathrm{O}_{7}, 0.1 \mathrm{~mm}$ $\mathrm{NaVO}_{3}$, and protease inhibitors (1 mM PMSF, $20 \mu \mathrm{g} / \mathrm{ml}$ of leupeptin, $2 \mu \mathrm{g} / \mathrm{ml}$ of pepstatin, $2 \mathrm{~mm}$ benzamidine $\mathrm{HCl}$, and 0.2 $\mathrm{mg} / \mathrm{ml}$ of bacitracin). The suspension was split into three tubes, each with $25 \%$ (for fraction 1 . WCE), $25 \%$ (for fractions 2 . Sup and 3. Pel), and $50 \%$ (for fractions 4-7) of the total. Spheroplasts were lyzed by adding Triton X-100 to $0.25 \%$ and incubating on ice for 5 min with gentle mixing. Lysate was underlayered with $50 \%$ volume of $30 \%$ sucrose (volume refers to the volume of the spheroplast suspension in EB; the same below), and spun at $12,000 \mathrm{rpm}$ for $10 \mathrm{~min}$ at $4^{\circ} \mathrm{C}$. Pellet was washed with $25 \%$ volume of EB containing $0.25 \%$ Triton X-100 (EBX), and spun again at $10,000 \mathrm{rpm}$ for $5 \mathrm{~min}$ at $4^{\circ} \mathrm{C}$. The crude chromatin pellet for fractions 4-7 was incubated in $50 \%$ volume of EBX at 
$37^{\circ} \mathrm{C}$ for $2 \mathrm{~min} . \mathrm{CaCl}_{2}$ (to $1 \mathrm{~mm}$ ) and $600 \mu \mathrm{m}$ units of $\mathrm{MN}$ ase were added, and incubation continued for $1 \mathrm{~min}$ with mixing. Digestion was stopped by adding EGTA to $1 \mathrm{~mm}$, and spun at $10,000 \mathrm{rpm}$ for $2 \mathrm{~min}$ at $4^{\circ} \mathrm{C}$. Pellet was digested once more with $200 \mu \mathrm{M}$ units of $\mathrm{MN}$ ase in $25 \%$ volume of EBX and spun as above. Supernatants were combined, and then split equally into two: one for fraction 4 ( $\mathrm{M} \mathrm{N}$ ase Sup) and the other for high speed fractions 6 and 7. The latter was centrifuged at 100,000 $\mathrm{g}(50,000$ rpm in Beckman TLA-100.3 rotor) for $1 \mathrm{hr}$ at $4^{\circ} \mathrm{C}$. All pellet fractions were resuspended in EBX, and the volumes of all fractions were adjusted with EBX $(\sim 60 \mu$ l final volume) to reflect the same cell equivalent. Equal volumes of $2 \times$ Laemmli's buffer were added to each fraction. Samples were boiled for $3 \mathrm{~min}$, and spun at $10,000 \mathrm{rpm}$ for $1 \mathrm{~min}$ before loading to $12.5 \%$ SDSPAGE gels.

Random mutagenesis of CDC 6 and isolation of new cdc6 temperature-sensitive mutants

The CDC 6 gene was amplified from pKS-CDC 6 by PCR using universal sequencing (T7) and reverse sequence primers from the vector. PCR was performed using five units of AmpliTag polymerase (Perkin-Elmer) in $100 \mu \mathrm{l}$ of standard buffer from the manufacturer plus $0.1 \mathrm{ng}$ of template, 50 pmoles each of primers and $20 \mathrm{~mm}$ each of dNTP for 25 cycles of $\left(94^{\circ} \mathrm{C}, 1 \mathrm{~min} ; 54^{\circ} \mathrm{C}, 1\right.$ min; $72^{\circ} \mathrm{C}, 3 \mathrm{~min}$ ) after an initial $2 \mathrm{~min}$ at $94^{\circ} \mathrm{C}$. PCR products were cut with $\mathrm{Xhol}$ and $\mathrm{HindIII}$, and the $2.1-\mathrm{kb}$ fragment was gel purified and cloned into pRS415 cut with the same enzymes. Plasmids were transformed into $\mathrm{E}$. coli and recovered from $\sim 60,000$ pooled primary transformants.

Plasmids $(5 \mu \mathrm{g})$ from the mutagenized library were transformed into YB0209. After incubation at $25^{\circ} \mathrm{C}$ for 4 days, $\sim 14,000$ transformants that were in the range of $200-300$ colonies/ plate were replica-plated onto two sets of FOA-Leu plates, and incubated at 25 or $37^{\circ} \mathrm{C}$. Plasmids from temperature-sensitive colonies were retested by the same plasmid shuffle. Two mutants were sequenced with $\mathrm{ABI} 377$ sequencer (Perkin Elmer): cdc6-2 has A320S (GCA $\rightarrow$ tCA), L338L (TTA $\rightarrow$ cTA) and L450S (TTA $\rightarrow$ TCA), and cdc6-3 has H144T (CAT $\rightarrow$ tAT) and L258S (TTA $\rightarrow$ TCA).

\section{Fluorescence microscopy, two-dimensional gels, and FACS}

Fluorescence microscopy (Diffley et al. 1994) and two-dimensional gels (Liang et al. 1995) were performed essentially as described. For FACS, $\sim 5 \times 10^{6}$ cells for each sample were fixed in $70 \%$ ethanol, resuspended in $50 \mathrm{~mm}$ sodium citrate $(\mathrm{pH} \mathrm{7.2)}$, briefly sonicated, digested with $0.25 \mathrm{mg} / \mathrm{ml} \mathrm{RN}$ ase in the same buffer followed by $1 \mathrm{mg} / \mathrm{ml}$ of proteinase $K$, each for $1 \mathrm{hr}$ at $50^{\circ} \mathrm{C}$. DN A was stained with $10 \mu \mathrm{g} / \mathrm{ml}$ of propidium iodide, and 50,000 cells from each sample were scanned with Elite (Coulter) or FACSCalibur (Becton-Dickinson) FACS machine.

\section{Histone $\mathrm{H} 1$ kinase assay and Western blotting}

Sucl/p13 bead precipitation and histone $\mathrm{H} 1$ kinase assay were according to Elsasser et al. (1996). Extract containing $250 \mu \mathrm{g}$ of proteins from each sample was used for the kinase assay. For Western blotting, proteins were transferred to nitrocellulose, and blocked with $5 \%$ dry milk in TBST ( $0.1 \%$ Tween 20$)$. M onoclonal antibodies (mAb) from ascites against Orc1-Orc6 subunits were SB35, 46, 3, 12, 5, and 49 in dilutions of 1:1000, $1: 500,1: 50,000,1: 2000,1: 2000$, and 1:2000, respectively, plus SB16 against Orclp in 1:2000. $\mathrm{M} \mathrm{cm} 2$ and $\mathrm{M} \mathrm{cm} 3 \mathrm{mAb}$ were 28 and 18 , respectively, both in 1:10,000. Horseradish peroxidasecoupled anti-mouse secondary antibody was used in 1:10,000 in TBST containing $5 \%$ dry milk. Reactive bands were visualized with the SuperSignal or SuperSignal ULTRA chemiluminescent kit (Pierce).

\section{Acknowledgments}

We thank Michael Weinreich for providing bORC and orc6 phosphorylation mutant, and for discussions and reading of the manuscript, Masahiro Akiyama for MCM antibodies and bMCM, Stephen Bell for ORC antibodies, and Gavin Sherlock and Bruce Futcher for the cdc6s strain, mostly before publication. We also thank Corine Driessens for technical assistance, Pat Burfiend and M aria Coronesi for FACS analysis, Gavin Sherlock for help with fluorescence microscopy, Alain Verreault for discussion on M N ase digestion, James Duffy for art work, and Philip Renna for photography. This work was supported by a grant from N ational Institutes of Health (GM 45436 to B.S.) and a postdoctoral fellowship from the Cancer Research Fund of the Damon Runyon-Walter Winchell Foundation (DRG-1308 to C.L.).

The publication costs of this article were defrayed in part by payment of page charges. This article must therefore be hereby marked "advertisement" in accordance with 18 USC section 1734 solely to indicate this fact.

\section{References}

Bell, S.P. and B. Stillman. 1992. ATP-dependent recognition of eukaryotic origins of DNA replication by a multiprotein complex. Nature 357: 128-134.

Bell, S.P., R. Kobayashi, and B. Stillman. 1993. Yeast origin recognition complex functions in transcription silencing and DN A replication. Science 262: 1844-1870.

Bell, S.P., J. Mitchell, J. Leber, R. Kobayashi, and B. Stillman. 1995. The multidomain structure of ORC 1p reveals similarity to regulators of DNA replication and transcriptional silencing. Cell 83: 563-568.

Bueno, A. and P. Russell. 1992. Dual functions of CDC6: A yeast protein required for DNA replication also inhibits nuclear division. EMBO J. 11: 2167-2176.

Chong, J.P.J., H.M. Mahbubani, C.-Y. Khoo, and J.J. Blow. 1995. Purification of an MCM-containing complex as a component of the DNA replication licensing system. Nature 375: 418421.

Chong, J.P.J., P. Thommes, and J.J. Blow. 1996. The role of MCM/P1 proteins in the licensing of DNA replication. Trends Biochem. Sci. 21: 102-106.

Cocker, J.H., S. Piatti, C. Santocanale, K. N asmyth, and J.F.X. Diffley. 1996. An essential role for the C dc6 protein in forming the pre-replicative complexes of budding yeast. Nature 379: 180-182.

Coleman, T.R., P.B. Carpenter, and W.G. Dunphy. 1996. The Xenopus Cdc6 protein is essential for the initiation of a single round of DNA replication in cell-free extracts. Cell 87: $53-63$.

Conradt, B., J. Shaw, T. Vida, S. Emr, and W. Wickner. 1992. In vitro reactions of vacuole inheritance in Saccharomyces cerevisiae. J. Cell Biol. 119: 1469-1479.

Dahmann, C., J.F.X. Diffley, and K.A. N asmyth. 1995. S-phasepromoting cyclin-dependent kinases prevent re-replication by inhibiting the transition of replication origins to a prereplicative state. Curr. Biol. 5: 1257-1269.

Dalton, S. and L. Whitbread. 1995. Cell cycleregulated nuclear import and export of Cdc47, a protein essential for initiation of DNA replication in budding yeast. Proc. Natl. Acad. Sci. 92: 2514-2518. 
Detweiler, C.S. and J.J. Li. 1997. Cdc6p establishes and maintains a state of replication competence during $\mathrm{G}_{1}$ phase. J. Cell Sci. 110: 753-763.

Diffley, J.F.X. 1996. Once and only once upon a time: Specifying and regulating origins of DNA replication in eukaryotic cells. Genes \& Dev. 10: 2819-2830.

Diffley, J.F.X. and J.H. Cocker. 1992. Protein-DNA interactions at a yeast replication origin. Nature 357: 169-172.

Diffley, J.F.X., J.H. Cocker, S.J. Dowell, and A. Rowley. 1994. Two steps in the assembly of complexes at yeast replication origins in vivo. Cell 78: 303-316.

Donovan, S., J. Harwood, L.S. Drury, and J.F.X. Diffley. 1997. Cdc6p-dependent loading of $\mathrm{M} \mathrm{cm}$ proteins onto pre-replicative chromatin in budding yeast. Proc. Natl. Acad. Sci. 94: 5611-5616.

Elsasser, S., F. Lou, B. Wang, J.L. Campbell, and A. Jong. 1996. Interaction between yeast Cdc6 protein and B-type cyclin/ Cdc28 kinases. Mol. Biol. Cell 7: 1723-1735.

Fox, C.A., S. Loo, A. Dillin, and J. Rine. 1995. The origin recognition complex has essential functions in transcriptional silencing and chromosomal replication. Genes \& Dev. 9: 911-924.

Gibson, S.I., R.T. Surosky, and B.-K. Tye. 1990. The phenotype of the minichromosome maintenance mutant $\mathrm{mcm} 3$ is characteristic of mutants defective in DNA replication. Mol. Cell. Biol. 10: 5707-5720.

Heichman, K.A. and J.M. Roberts. 1996. The yeast CDC16 and CDC27 genes restrict DN A replication to once per cell cycle. Cell 85: 39-48.

Hennessy, K.M ., A. Lee, E. Chen, and D. Botstein. 1991. A group of interacting yeast DNA replication genes. Genes \& Dev. 5: 958-969.

Hua, X.H., H. Yan, and J. N ewport. 1997. A role for Cdk2 kinase in negatively regulating DNA replication during $S$ phase of the cell cycle. J. Cell Biol. 137: 183-192.

Jallepalli, P.V. and T. Kelly. 1997. Cyclin-dependent kinase and initiation at eukaryotic origins: A replication switch? Curr. Opin. Cell Biol. 9: 358-363.

Katayama, T. 1994. The mutant DnaAcos protein which overinitiates replication of the Escherichia coli chromosome is inert to negative regulation for initiation. J. Biol. Chem. 269: 22072-22079.

Katayama, T. and A. Kornberg. 1994. Hyperactive initiation of chromosomal replication in vivo and in vitro by a mutant initiator protein, DnaAcos, of Escherichia coli. J. Biol. Chem. 269: 12698-12703.

Kimura, H., N. Takizawa, N. N ozaki, and K. Sugimoto. 1995. Molecular cloning of CDNA encoding mouse Cdc21 and CDC46 homologs and characterization of the products: Physical interaction between P1(MCM3) and CDC46 proteins. Nucleic Acids Res. 23: 2097-2104.

Klemm, R.D., R.J. Austin, and S.P. Bell. 1997. Coordinate binding of ATP and origin DN A regulates the ATPase activity of the origin recognition complex. Cell 88: 493-502.

Kubota, Y., S. Mimura, S.-I. Nishimoto, H. Takisawa, and H. $\mathrm{N}$ ojima. 1995. Identification of the yeast MCM 3-related protein as a component of Xenopus DNA replication licensing factor. Cell 81: 601-609.

Landis, G., R. Kelley, A.C. Spradling, and J. Tower. 1997. The $\mathrm{k} 43$ gene, required for chorion gene amplification and di ploid cell chromosome replication, encodes the Drosophila homolog of yeast origin recognition complex subunit 2. Proc. Natl. Acad. Sci. 94: 3888-3892.

Lei, M., Y. Kawasaki, and B.-K. Tye. 1996. Physical interactions among $\mathrm{Mcm}$ proteins and effects of $\mathrm{Mcm}$ dosage on DNA replication in Saccharomyces cerevisiae. Mol. Cell. Biol.
16: 5081-5090.

Liang, C., M. Weinreich, and B. Stillman. 1995. ORC and Cdc6p interact and determine the frequency of initiation of DNA replication in the genome. Cell 81: 667-676.

Loo, S., C.A. Fox, J. Rine, R. Kobayashi, B. Stillman, and S. Bell. 1995. The origin recognition complex in silencing, cell-cycle progression and DN A replication. Mol. Biol. Cell 6: 741-756.

Madine, M.A., C.-Y. Khoo, A.D. Mills, and R.A. Laskey. 1995. MCM 3 complex required for cell cycle regulation of DNA replication in vertebrate cells. Nature 375: 421-424.

Muzi-Fal coni, M., G.T.W. Brown, and T.J. Kelly. 1996. cdc18+ regulates initiation of DNA replication in Schizosaccharomyces pombe. Proc. Natl. Acad. Sci. 93: 1566-1570.

Nasmyth, K. 1996. Putting the cell cycle in order. Science 274: 1643-1645.

Nishitani, H. and P. N urse. 1995. p65 ${ }^{\text {cdc18 }}$ plans a major role controlling the initiation of DNA replication in fission yeast. Cell 83: 397-405.

Piatti, S., C. Lengauer, and K. N asmyth. 1995. Cdc6 is an unstable protein whose de novo synthesis in $G_{1}$ is important for the onset of S phase and for preventing a "reductional" anaphase in the budding yeast Saccharomyces cerevisiae. EMBO J. 1141: 3788-3799.

Piatti, S., T. Bohm, J.H. Cocker, J.F.X. Diffley, and K. N asmyth. 1996. Activation of S-phase-promoting CDKs in late $G_{1}$ defines a "point of no return" after which Cdc6 synthesis cannot promote DNA replication in yeast. Genes \& Dev. 10: 1516-1531.

Schneider, B.L., B. Stein, W. Seufert, and A.B. Futcher. 1996. pM PY-ZAP: A reusable polymerase chain reaction-directed gene disruption cassette for Saccharomyces cerevisiae. Yeast 12: 129-134.

Schwob, E., T. Bohm, M.D. M endenhall, and K. N asmyth. 1994. The B-type cyclin kinase inhibitor $\mathrm{p} 40^{\mathrm{SICl}}$ controls the $\mathrm{G}_{1}$ to S transition in S. cerevisiae. Cell 79: 233-244.

Singer, J.D., B.M. M anning, and T. Formosa. 1996. Coordinating DN A replication to produce one copy of the genome requires genes that act in ubiquitin metabolism. Mol. Cell. Biol. 16: 1356-1366.

Skarstad, K. and E. Boye. 1994. The initiator protein DnaA: Evolution, properties and function. Bioch. Bioph. Acta 1217: 111-130.

Stillman, B. 1996. Cell cycle control of DNA replication. Science 274: 1659-1664.

Tanaka, T., D. Knapp, and K. N asmyth. 1997. Loading of an $\mathrm{Mcm}$ protein onto DNA replication origins is regulated by Cdc6p and CDKs. Cell 90: 649-660.

Todorov, I.T., A. Attaran, and S.E. Kearsey. 1995. BM 28, a human member of the MCM2-3-5 family, is displaced from chromatin during DNA replication. J. Cell Biol. 129: 14331445.

Yan, H., A.M. Merchant, and B.-K. Tye. 1993. Cell cycleregulated nuclear localization of MCM 2 and MCM 3, which are required for the initiation of DN A synthesis at chromosomal replication origins in yeast. Genes \& Dev. 7: 2149-2160.

Zhou, C. and A. Jong. 1990. CDC6 mRNA fluctuates periodically in the yeast cell cycle. J. Biol. Chem. 265: 19904-19909.

Zwerschke, W., H.-W. Rottjakob, and H. Kuntzel. 1994. The Saccharomyces cerevisiae CDC 6 gene is transcribed at late mitosis and encodes a ATP/GTPase controlling S phase initiation. J. Biol. Chem. 269: 23352-23356. 


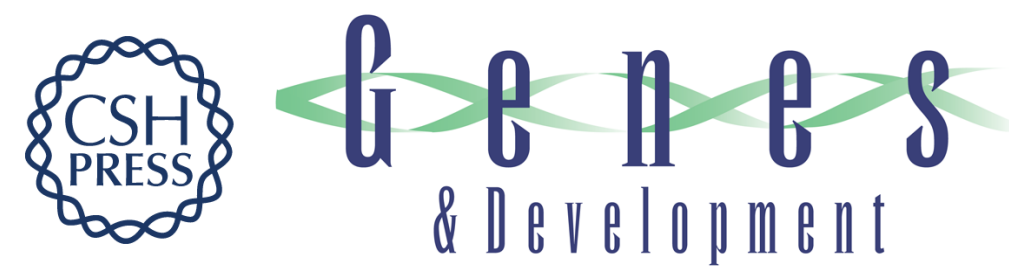

\section{Persistent initiation of DNA replication and chromatin-bound MCM proteins during the cell cycle in cdc6 mutants}

Chun Liang and Bruce Stillman

Genes Dev. 1997, 11:

Access the most recent version at doi:10.1101/gad.11.24.3375

References

This article cites 48 articles, 23 of which can be accessed free at: http://genesdev.cshlp.org/content/11/24/3375.full.html\#ref-list-1

License

Email Alerting

Receive free email alerts when new articles cite this article - sign up in the box at the top Service right corner of the article or click here.

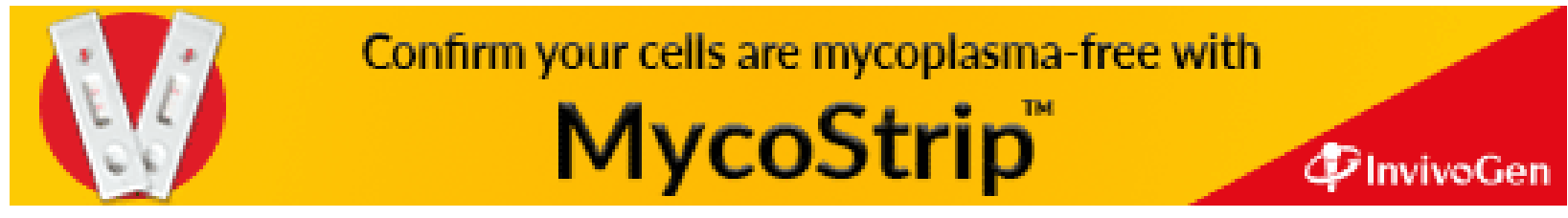

